\title{
Transmission of Helicobacter pylori infection
}

\begin{abstract}
Helicobacter pylori is one of the world's most common bacterial infections, as more than three quarters of the population of the developing world are infected from an early age. The pattern in the developed world is different, where infection in childhood is less common but with a gradual increase in prevalence with age. ${ }^{1-4}$ The mode of transmission of $H$ pylori is assuming greater importance as the public health implications of infection become clearer. Understanding the mode of transmission is important as reinfection after eradication of the organism is a particular concern. This review summarises our understanding of the source, transmission, and changing trends of infection, and the implications for reinfection after eradication.
\end{abstract}

\section{Sources of $\boldsymbol{H}$ pylori infection}

Humans are the sole natural host of $H$ pylori, although closely similar organisms have been found in primates. ${ }^{5}$ It has never been isolated from the environment, but would be difficult to culture from contaminated sources as it grows more slowly in vitro than most other organisms. $H$ pylori DNA has been detected by polymerase chain reaction in Peruvian sewage water. $^{6}$ Whether this represents the detection of viable organisms or reflects a lack of specificity is unclear. In vitro experiments have shown that $H$ pylori survives for several days in distilled water, saline, and sea water if these are kept cool, but becomes non-culturable after one to three days at room temperature. ${ }^{7}$ Whether particulate matter could increase survival time by providing a more favourable local environment is unknown.

It is unlikely that $H$ pylori can multiply in the environment, and it seems almost certain that humans are the only source of infection.

\section{Route of infection}

The ability of the organism to survive in the environment has implications for the transmission of infection. Faecooral transmission is not usually a direct interpersonal one but relies on environmental contamination. Oro-oral transmission usually requires direct interpersonal contact.

From its protected niche in the gastric mucosa, $H$ pylori could either be transmitted by the oro-oral route with episodes of gastro-oesophageal reflux permitting access to the mouth, or excreted in faeces. $H$ pylori has now been cultured both from the faeces ${ }^{8}$ and from dental plaque ${ }^{9} 10$ on a small number of occasions, but has been identified by polymerase chain reaction from both sites in a greater number of subjects with infection, ${ }^{11-13}$ suggesting that transmission by both routes can occur.

Epidemiological evidence suggests transmission by both routes. The increased rates of infection among children of West African mothers who premasticate their infants' food $^{14}$ and among Chinese who share eating utensils favours oro-oral transmission. Gnotobiotic beagles who have oro-oral contact transmit $H$ pylori to each other..$^{15} \mathrm{An}$ increased rate of infection, however, among dental workers has not been found, ${ }^{16}$ but endoscopists not using gloves have an increased rate of infection. ${ }^{17}$ The main epidemiological evidence supporting faeco-oral transmission is the similarity of the seroepidemiology with that of hepatitis A. ${ }^{18}$

\section{Clustering of $\boldsymbol{H}$ pylori infection: is the family an important source of acquisition?}

The absence of an environmental reservoir for $H$ pylori suggests interpersonal transmission. Clustering of $\mathrm{H}$ pylori infection among people living in close proximity to each other has been described in childrens' institutions ${ }^{19}$ and in the family. ${ }^{20} 21$ This suggests interpersonal transmission but is consistent with a common environmental source. If there is true clustering of infection within families, then this taken together with the failure to find an environmental reservoir represents powerful evidence for direct or indirect interpersonal transmission.

Interpretation of family studies is not straightforward. Studies of index children have generally shown an increased rate of infection in the families of seropositive children, but there have been no controlled studies for variation in socioeconomic circumstances of the families. Hence the findings may merely represent greater environmental exposure of the index positive children. Studies of the spouses of index adults, on the other hand have generally shown no increased rates of infection. The largest study, among 277 couples in a fertility clinic, which was both the only one with sufficient power to detect modest effects and the only one to control for socioeconomic circumstances, showed no increased rate of infection among the spouses of seropositive index 
cases. ${ }^{22}$ Two smaller studies have confirmed this finding, ${ }^{23} 24$ but one did not. ${ }^{25}$ Studies of the children of index adults have given different results, ${ }^{23-25}$ but the problems of size of study and controlling for socioeconomic circumstances apply to them all. Thus, from family studies so far it is not possible to say whether true clustering occurs.

Evidence of a different type comes from a limited number of DNA and RNA typing studies, which are the only useful typing schemes for epidemiological purposes. There is great variability in the DNA and RNA profiles by restriction endonuclease analysis. ${ }^{26}$ The only context in which identical strains may be found by DNA analysis is on separate occasions in the stomach of a subject or in infected family members. $H$ pylori is a longlasting infection in its protected niche in the stomach, allowing time for genetic evolution to occur over several decades. Hence finding different strains of organism in two family members may only mean that transmission was not recent. Clonal variants of the same strain of the organism have been found in three generations of a single family, ${ }^{27}$ suggesting that the opportunity for genetic evolution of the organism may only be of limited importance.

There are four studies of family members using either DNA or RNA fingerprinting, and they give different results. In the first report by Langenburg of a duodenal ulcer family, seven of eight members had the same strain of $H$ pylori. This study only used one restriction enzyme, thus limiting the range of strains that could be detected. In another report, however, of a duodenal ulcer family by Nwokolo using a larger number of restriction enzymes, only three of nine subjects from three generations tested had the same strain. ${ }^{27}$ Tee used ribosomal RNA to study seven family groups and found identical digest patterns in members of two families, with variability in strains detected among members of the remaining families, usually husband/wife combinations. ${ }^{28}$ In a further study using ribotyping, seven members of three families were studied, with identical isolates being found in mother, father, and son of one family, but different strains in the other two families. ${ }^{29}$ Finally, one other report of just two pairs of siblings reported different strains in each. ${ }^{30}$

This evidence does not prove direct interpersonal transmission, but is consistent with spread of infection within the home and also, perhaps more importantly, with acquisition from outside the home. Given that humans are probably the only source of infection, it seems reasonable to conclude that in the developed world at least, interpersonal transmission is occurring, but that the people from whom it is acquired are not restricted to the family.

\section{Age of acquisition and risk factors for infection}

Two cohort studies suggest that the incidence of infection in adults in the developed world is low, about $0.5 \%$ per year. ${ }^{31}$ Coupled with a small spontaneous eradication rate, these rates are too low to explain the prevalence of infection among the subjects being studied. This suggests that some sort of birth cohort phenomenon is in operation. Evidence from the follow up of subjects after eradication of infection supports these findings, although reinfection may not be the same as primary infection. ${ }^{32} \mathrm{~A}$ study from the developing world where $20 \%$ per year of adults whose infection had been cured were reinfected, suggests that if there were susceptible adults in this environment they would rapidly re-acquire $H$ pylori. ${ }^{33}$

We and others have shown a strong association between adult seropositivity and overcrowding in the childhood home independently of father's social class in the developed world. ${ }^{3} 34 \mathrm{We}$ also showed a strong independent relation with no fixed hot water supply in the childhood home. Adult risk factors in our own cross sectional study for seropositivity at all ages were much weaker than childhood risk factors, suggesting that most British adults acquired their infection in childhood.

The main adult risk factors were the number of children currently living in the home (but not the number who had left home) and marital status. Although the second has a stronger effect than the first it just failed to reach significance because of the small number of unmarried adults.

We studied 40 children of 20 seropositive children identified in this study, but found only one infected based on the ${ }^{13} \mathrm{C}$ urea breath test, ${ }^{23}$ suggesting that children are not the source of their parents infection or that they may be able to spontaneously eradicate infection. This study is also consistent with adults not infecting their children nowadays.

This evidence suggests that in more recent times a larger proportion of those infected are acquiring their infection at a later age, although childhood is still the most important period. Risk factors pertaining to adult life in older adults may be masked by the smaller proportion of susceptible subjects entering adult life.

\section{Susceptibility to infection}

The prevalence of infection among children in the developed world ranges from 5-15\% depending on socioeconomic conditions. ${ }^{1}{ }^{35-37}$ It has decreased in the developed world. It may be that environmental contamination has been reduced by improved living conditions and sanitation interfering mainly with faeco-oral transmission, or secondly host susceptibility to infection has diminished, interfering with both faeco-oral and oro-oral transmission.

Hepatitis A, a faeco-orally transmitted disease, has shown the same decline in prevalence as that seen for $H$ pylori. ${ }^{38}$ Improvements in sanitation and overcrowding have played a part. Epstein-Barr virus, an oro-orally transmitted infection, has shown a different pattern. In the developing world the whole population is infected by the age of 5 . In the developed world, as living conditions improve, an increasing proportion are infected in adolescence and young adulthood, from oro-oral contact with the opposite sex, the whole population being infected by the age of $30 .{ }^{39}$ The changing pattern may result from decreased family size and diminished contact with other children at a young age. If $H$ pylori is oro-orally transmitted, higher rates of infection in young adults would be expected than those seen. The risk factors found in adults, however, pertained mainly to young adults, in whom orooral transmission would be expected. If oro-oral transmission is important then changes in host susceptibility may partly explain the decline.

Gastric acid production may play a key part in the transmission of infection. $H$ pylori cannot survive for long in an acid environment despite being more acid resistant than other organisms. ${ }^{40}$ In the volunteer ingestion study by Marshall, ${ }^{41}$ the infecting dose was taken after premedication with cimetidine. Morris could only infect himself with $H$ pylori after premedicating himself with cimetidine, having failed to do so without. ${ }^{42}$

Ferrets, whose gastric physiology is similar to humans, are infected by $H$ mustelae bearing many similarities to $H$ pylori in humans. Forty one per cent of adult ferrets given omeprazole to neutralise the gastric contents had positive faecal cultures compared with $10 \%$ of ferrets not given the drug. ${ }^{43}$

A variety of bacterial and parasitic infections suppress gastric acid secretion in humans. ${ }^{44} 45$ Malnutrition is also a 
recognised cause of reduced gastric acid secretion. A study from the Gambia, where infection is common showed that children had a lower gastric acid secretion than British children, comparable with that of adults taking $\mathrm{H}_{2}$ antagonists. Although temporary achlorhydria is associated with $H$ pylori infection, this is probably not the whole explanation.

Transmission of $H$ pylori may have fallen as a result of the general reduction of infection and malnutrition resulting from improved living conditions that have taken place this century, particularly among children, both by decreasing factors that facilitate transmission, as well as decreasing transmission of the organism itself.

\section{Conclusion}

$H$ pylori can survive for at least limited periods in the environment, and with humans being the only source of infection, either direct or indirect interpersonal transmission could occur by either the faeco-oral or oro-oral route. The first may be the more important in the developing world and the second in the developed world.

Infection with $H$ pylori is declining as living conditions improve. Acquisition is principally in childhood from both inside and outside the home. There is no justification for treating family contacts of subjects receiving eradication therapy, and reinfection after successful eradication is unlikely at least in the developed world.

Further studies in the developed world should concentrate on acquisition in childhood from sources outside the home such as schools.

Department of Medicine, M A MENDALL St George's Hospital Medical School, Cranmer Terrace, Tooting,

London SW17 ORE

1 Megraud F, Brassens RM, Denis F, Belbouri A, Hoa DQ Seroepidemiology of Campylobacter pylori infection in various populations. f Clin Microbiol 1989; 27: 1870-3.

2 Graham DY, Adam E, Reedy GT, Agarwal JP, Agarwal R, Evans DJ, et al. Seroepidemiology of Helicobacter pylori infection in India. Comparison of developing and developed countries. Dig Dis Sci 1991; 36: 1084-8.

3 Mendall MA, Goggin PM, Molineaux N, Levy J, Toosy T, Strachan D, et al. Childhood living conditions and Helicobacter pylori seropositivity in adult life [see comments]. Lancet 1992; 339: 896-7.

4 Sitas F, Forman D, Yarnell JW, Burr ML, Elwood PC, Pedley S, et al. Helicobacter pylori infection rates in relation to age and social class in a population of Welsh men. Gut 1991; 32: 25-8.

5 Goodwin CS, McConnell W, McCulloch RK, McCullough C, Hill R, Bronsdon MA, et al. Cellular fatty acid composition of Campylobacter pylori from primates and ferrets compared with those of other campylobacters. f Clin Microbiol 1989; 27: 938-43.

6 Westblom T, Fritz S, Phadnis S, Midkiff B, Leon-Barua R, Recaverren S, et al. PCR analysis of Peruvian sewage water: support for fecal-oral spread of Helicobacter pylori. Acta Gastroenterol Belg 1993; 56 (suppl): 47 .

7 West AP, Millar MR, Tompkins DS. Survival of Helicobacter pylori in water and saline [Letter]. $\mathcal{F}$ Clin Pathol 1990; 43: 609.

8 Thomas JE, Gibson GR, Darboe MK, Dale A, Weaver LT. Isolation of Helicobacter pylori from human faeces. Lancet 1992; 340: 1194-5.

9 Majmudar P, Shah SM, Dhunjibhoy KR, Desai HG. Isolation of Helicobacter pylori from dental plaques in healthy volunteers. Indian $\mathcal{f}$ Gastroenterol 1990; 9: 271-2.

10 Shames B, Krajden S, Fuksa M, Babida C, Penner JL. Evidence for the occurrence of the same strain of Campylobacter pylori in the stomach and dental plaque. f Clin Microbiol 1989; 27: 2849-50

11 Mapstone N, Lynch D, Lewis F, Axon A, Tompkins D, Dixon M, et al. PCR identification of Helicobacter pylori in faeces from gastritis patients. Lancet 1993; 341: 447.

12 Banarvala N, Lopez C, Owen R, Abdi Y, Davies G, Hardie J, et al. Helicobacter pylori in dental plaque. Lancet 1993; 341: 380 .

13 Nguyen AM, Engstrand L, Genta RM, Graham DY, el Zaatari F. Detection of Helicobacter pylori in dental plaque by reverse transcription-polymerase chain reaction. $\mathcal{f}$ Clin Microbiol 1993; 31: 783-7.
14 Albenque M, Tall F, Dabis F, Megraud F. Epidemiological study of transmission from mother to child in Africa. Rev Esp Enferm Dig 1990; 78 (suppl 1): 48

15 Lee A, Fox JG, Otto G, Dick EH, Krakowka S. Transmission of Helicobacter spp. A challenge to the dogma of faecal-oral spread. Epidemiol Infect 1991; 107: 99-109.

16 Malaty HM, Evans DJ, Abramovitch K, Evans DG, Graham DY. Helicobacter pylori infection in dental workers: a seroepidemiology study. Am $\mathcal{f}$ Gastroenterol 1992; 87: 1728-31.

17 Mitchell HM, Lee A, Carrick J. Increased incidence of Campylobacter pylori infection in gastroenterologists: further evidence to support personto-person transmission of $\mathrm{C}$ pylori. Scand $\mathcal{f}$ Gastroenterol 1989; 24: to-person

18 de Korwin J, Remot P, Hartemann P, Catelle A, Conroy M, Schmitt J. Association of A hepatitis seropositivity with Helicobacter pylori gastric infection supporting a person to person transmission of HP. Irish Med $\mathcal{J}$ 1982; 161 (suppl): $60-1$.

19 Berkowicz J, Lee A. Person-to-person transmission of Campylobacter pylori [Letter]. Lancet 1987; ii: 680-1.

20 Drumm B, Perez PG, Blaser MJ, Sherman PM. Intrafamilial clustering of Helicobacter pylori infection. $N$ Engl f Med 1990; 322: 359-63.

21 Mitchell HM, Bohane TD, Berkowicz J, Hazell SL, Lee A. Antibody to Campylobacter pylori in families of index children with gastrointestinal illness due to $C$ pylori [Letter]. Lancet 1987; 2: 681-2.

22 Perez PG, Witkin SS, Decker MD, Blaser MJ. Seroprevalence of Helicobacter pylori infection in couples. 7 Clin Microbiol 1991; 29: 642-4.

23 Mendall M, Molineaux N, Strachan D, Northfield T. Transmission of Helicobacter pylori in families. Gut 1993; 34 (suppl 1): 53.

24 Jones DM, Eldridge J, Whorwell PJ. Antibodies to Campylobacter pyloridis in household contacts of infected patients. Br Med F Res 1987; 294: 615 .

25 Graham D, Malaty H, Klein PD, Evans D, Evans D, Adam E. Helicobacter pylori infection clusters in families. Rev Esp Enferm Digest 1990; 78 (suppl): 26.

26 Langenberg W, Rauws EA, Widjojokusumo A, Tytgat GN, Zanen HC. Identification of Campylobacter pyloridis isolates by restriction endonuclease DNA analysis. $\mathcal{F}$ Clin Microbiol 1986; 24 : 414-7.

27 Nwokolo CU, Bickley J, Attard AR, Owen RJ, Costas M, Fraser IA Evidence of clonal variants of Helicobacter pylori in three generations of a duodenal ulcer disease family. Gut 1992; 33: 1323-7.

28 Tee W, Lambert J, Smallwood R, Schembri M, Ross BC, Dwyer B. Ribotyping of Helicobacter pylori from clinical specimens. $\mathcal{F}$ Clin Microbiol 1992; 30: 1562-7.

29 Bamford K, Collins J, Bickley J, Johnston B, Potts S, Boston V. Helicobacter pylori: comparison of DNA fingerprints provides evidence for intrafamilial infection. Irish $\mathcal{F}$ Med Sci 1992; 161 (suppl): 18.

30 Simor AE, Shames B, Drumm B, Sherman P, Low DE, Penner JL. Typing of Campylobacter pylori by bacterial DNA restriction endonuclease analysis and determination of plasmid profile. $\mathcal{F}$ Clin Microbiol 1990; 28: 83-6.

31 Parsonnet J, Blaser MJ, Perez PG, Hargrett BN, Tauxe RV. Symptoms and risk factors of Helicobacter pylori infection in a cohort of epidemiologists. Gastroenterology 1992; 102: 41-6.

32 Borody T, Andrews P, Mancuso N, Jankiewicz E, Brandl S. Helicobacter pylori reinfection 4 years post-eradication [Letter]. Lancet 1992; 339: 1295 .

33 Coelho LG, Passos MC, Chausson Y, Costa EL, Maia AF, Brandao MJ, et al. Duodenal ulcer and eradication of Helicobacter pylori in a developing country. An 18-month follow-up study. Scand $\mathcal{F}$ Gastroenterol 1992; 27: 362-6.

34 Galpin OP, Whitaker CJ, Dubiel AJ. Helicobacter pylori infection and overcrowding in childhood [Letter]. Lancet 1992; 339: 619.

35 Eldridge J, Jones D. Longitudinal study of the incidence of antibody to Campylobacter pylori in school children. Bordeaux: Gastroduodenal Pathology and Campylobacter pylori Workshop, 1988: 120.

36 Fiedorek SC, Malaty HM, Evans DL, Pumphrey CL, Casteel HB, Evans DJ, et al. Factors influencing the epidemiology of Helicobacter pylori infection in children. Pediatrics 1991; 88: 578-82.

37 Hardikar W, Davidson PM, Cameron DJ, Gilbert GL, Campbell PE, Smith AL. Helicobacter pylori infection in children. $\mathcal{F}$ Gastroenterol Hepatol 1991 ; 6: $450-4$.

38 Szmuness W, Dienstag JL, Purcell RH, Stevens CE, Wong DC, Ikram H, et al. The prevalence of hepatitis A in various parts of the world. et al. The prevalence of hepatitis

39 Adams E. The transmission of EBV infections. In: Hooks JG, ed. Viral infections in oral medicine. New York: Elsevier, 1982: 211-25.

40 Marshall BJ, Barrett LJ, Prakash C, McCallum RW, Guerrant RL. Urea protects Helicobacter (Campylobacter) pylori from the bactericidal effect of acid. Gastroenterology 1990; 99: 697-702.

41 Marshall BJ, Armstrong JA, McGechie DB, Glancy RJ. Attempt to fulfil Koch's postulates for pyloric Campylobacter. Med $\dot{f}$ Aust 1985; 142: 436-9.

42 Morris A, Nicholson G. Ingestion of Campylobacter pyloridis causes gastritis and raised fasting gastric pH. Am f Gastroenterol 1987; 82: 192-9.

43 Fox JG, Paster BJ, Dewhirst FE, Taylor NS, Yan LL, Macuch PJ, et al. Helicobacter mustelae isolation from feces of ferrets: evidence to support fecal-oral transmission of a gastric Helicobacter. Infect Immun 1992; 60: 606-11.

44 Chang H-C. Gastric secretion in fever and infectious diseases. $\mathcal{f}$ Clin Invest 1993; 12: 155-69. 45 Sarker S, Gyr K. Non-immunological defence mechanisms of the gut. Gut
1992; 33: 987-93. 